\title{
A Geriatric Educational Resource
}

\author{
Michael Lye \\ On behalf of the Working Party
}

Geriatric Medicine, University Clinical Department, Liverpool, UK

Dear Sir,

It is generally acknowledged that the demographic shift towards an ageing population taking place in Europe, the Americas and South East Asia will increase demands for health care and social support as a consequence of age-related pathology. These demands will impact economically over the next 10-30 years. Better medical management of disease(s) in older patients may well contain a proportion, at least, of this rising expenditure.

The knowledge, skills and attitudes reflecting a positive approach to older patients by doctors are best presented during undergraduate training for all future doctors be they physicians, surgeons, psychiatrists or, indeed, in any other speciality. In addition, a minority of physicians should be encouraged to develop special expertise at the postgraduate level in the problems of the older patient. In order to promote these two processes, a number of geriatricians from European countries with active educational pro- grammes in geriatric medicine, along with observers from North and South America, met to develop a common core curriculum in geriatric medicine. This 2-day intensive workshop at the European Academy of Yuste, Spain, received prepared position papers, which were discussed, developed and finally agreed. These agreed core element undergraduate and postgraduate curricula are available from the undersigned. In addition they have been 'published' on the web: URL: www.yuste.org/edugeri.html.

My colleagues and I would be delighted to receive comments, criticisms, suggestions in order to increase the potential benefits across a wider geographical spectrum. A future progress will involve a linkage of the agreed curricula to appropriate resources located on the Internet. We see the development of 'a geriatric educational resource' as a major assistance to others with similar objectives.

\section{KARGER \\ Fax + 41613061234 \\ E-Mail karger@karger.ch} www. karger.com (c) 1999 S. Karger AG, Basel

0304-324X/99/0452-0120\$17.50/0

Accessible online at: http://BioMedNet.com/karger
Prof. Michael Lye, MD, FRCP

Geriatric Medicine, University Clinical Department

The Duncan Building, Daulby Street

Liverpool L69 3GA (UK)

Tel. +44 0151706 4062, Fax +44 0151706 4064, E-Mail germed@liv.ac.uk 